\title{
The Implementation of Realistic Mathematics Education Approach to Improve Students' Mathematical Communication Ability in Statistics Course
}

\author{
Lois Lamya Paroqii ${ }^{1, a}$, Mursalin ${ }^{1, b *} \&$ Marhami $^{1, c}$ \\ 1Department of Mathematics Education, Universitas Malikussaleh, Aceh Utara, Indonesia \\ a loislamyaparoqi@gmail.com; b mursalin@unimal.ac.id; c marhami@unimal.ac.id; \\ *Corresponding Author: mursalin@unimal.ac.id | Phone : +6285260880453
}

Received: 11 August 2020

Revised: 23 September 2020

Accepted: 2 October 2020

\begin{abstract}
The purpose of this study is to analize the improving of mathematical communication skills's students, the learning acktivities of student and student's response at Realistic Mathematics (RME) learning. The research is held at MTs.S Syamsudduha in 2018-2019 years, which using quasi experiment with a quantitative approach. This study used two samples, they are experiment's class as treatment class consists of 34 students and control's class which not give the treatment consists of 36 students which the sample was taken in this research used the technique sampling purposive. This data was obtained with test technique and observation sheet. Data is analyzed with $t$ test using SPSS 18 , the result show that there is an increasing of mathematical communication skills of student on statistical study with the Realistic Mathematics Education (RME) learning. This shows that value of n-gain on student's mathematical communication skill for experiment's class is 0,49 and control's class is 0,17 with significant $0,000<0,05$, thats mean there is an increasing in the learning process. So, RME learning can improve student's mathematical communication skills of students better than students who is taught by conventional learning.
\end{abstract}

Keywords: mathematical communication; realistic mathematics education; statistical;

\section{Introduction}

Education is essentially an effort to pass down values, which will be a guide and direction in carrying out daily life practices, education is used as a differentiator between past, present, and future generations, more advanced or more deteriorating in quality. So it can be said that the back and forth of the good and bad fibers of a civilization, a nation is very much determined by the educational process applied in a nation (STAI Gajah Putih Lecturer Team, 2018: 51). Education is carried out by a group of people to find identity, change attitudes, self-potential, and for social survival. So that the role of the teacher as an educator is very influential in the world of education, one of which is for the development of human life.

According to Law no. 14 of 2005 concerning Teachers and Lecturers, teachers are professional educators who have the main task of educating, teaching, guiding, directing, training, assessing, and evaluating students in early childhood education through formal primary and secondary education. From this explanation, we can understand that the role of teachers is very important in the process of creating a quality future generation of the nation, both intellectually and morally. In this case, teachers not only teach formal education but also non-formal education both in the school environment and in the surrounding community, so that a teacher becomes a figure who is emulated by his students. In Indonesia, the profession to be a teacher is very much, especially the profession of a teacher who holds mathematics learning. Mathematics is a way to find answers to problems faced by humans, a way of using information, using knowledge of shapes and sizes, using knowledge of calculating, and most importantly thinking for ourselves in seeing and using relationships, Hasratuddin (2014: 30). In addition, mathematics is one of the subjects studied from the basic education level to the tertiary level, because mathematical knowledge in general, not only found in schools but in daily life. One part of mathematics that plays an important role in everyday life is statistics lessons.

According to Adinawan (2016: 234), statistics is a science (scientific method) that studies ways of collecting data, compiling data, presenting data, analyzing data, and interpreting data, and how to draw logical conclusions based on these things. made accurate decisions. The concepts that exist in statistics are 
also widely used and applied in various fields of science, both in education and others such as religion, engineering, industry, economics, astronomy, biology, medicine, agriculture, and so on.

Based on the results of observations at MTs.S Syamsuddhuha school which has used the 2013 curriculum. Mathematics teachers stated that there are still many students who complain and find mathematics difficult. As for one example of a statistical question in class VII, the researcher made observations in class VII-1 which showed the importance of mathematical communication skills possessed by students. The picture below is one of the students' works in solving the statistical questions given by the researcher.

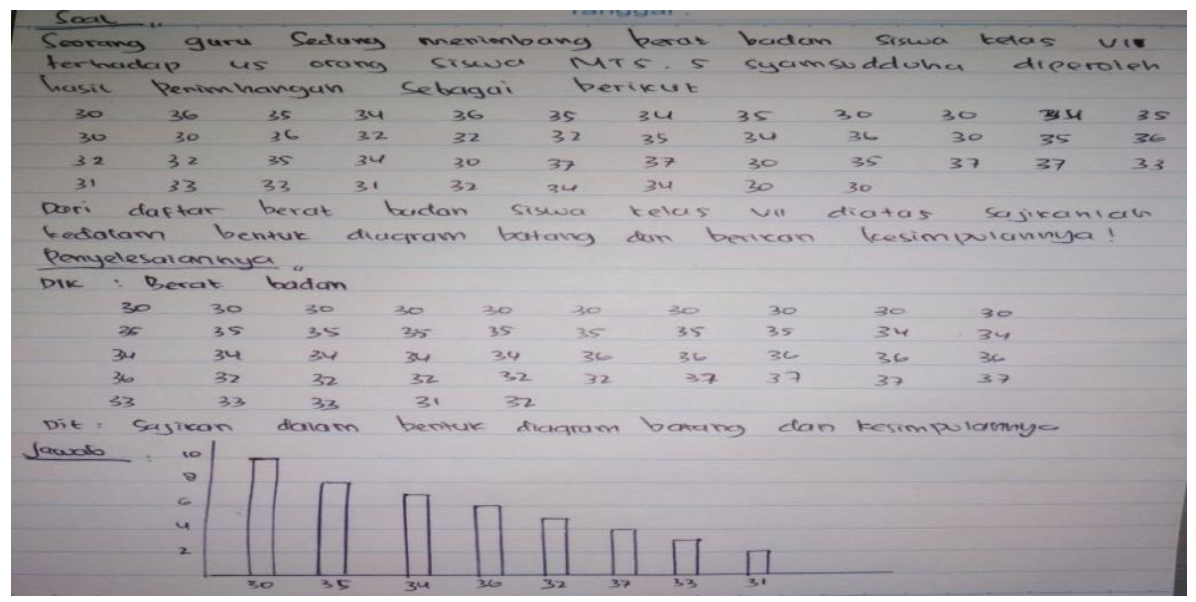

Figure 1. Results of Students' Work in Solving Mathematical Problems

Based on the results of student work shown in Figure 1, when students are given problems such as the example questions above, we can see that errors occur because:

- Students have not been able to understand the questions that have been presented because of their low mathematical communication skills so that students still have difficulty converting data into tables.

- Students have not been able to present any given data so that there is an error in the presentation of the bar chart.

- Students are still confused in stating the situation in the form of a picture and solving it.

- Students have not been able to compile mathematical models into diagrams.

- Students do not conclude the results of the existing problems.

Therefore, one of the reasons students have difficulty solving existing problems is due to the lack of mathematical communication skills of students. It is because students are still unable to state the situation in the form of pictures, tables and graphs so that students have not been able to compile into a mathematical model and solve it. Where students still have difficulty changing data from story questions into tables or graphs, therefore students have not been able to understand the questions that have been presented.

One of the causes of students having difficulty in working on questions is the lack of mathematical communication skills of students where students still have difficulty converting data from story form questions into graphs and vice versa. has been there. Because students' mathematical communication skills are still low, therefore, it is necessary to improve again.

This is in line with Purwandari's research (2014: 05), which argues that the difficulty of students in working on problems in the form of stories, graphs and diagrams is due to a lack of knowledge in modeling existing solutions into mathematics first. Thus students have not been able to understand the problems that have been presented by the teacher because their mathematical communication skills are still low.

In the learning process, the teacher is not yet accustomed to giving mathematical communication skills questions so that mathematics lessons are still less attractive to students, especially statistics lessons because the problems that have been presented by the teacher are more dominant in using questions from books or worksheets. Therefore, students are still confused in solving questions in the form of stories, graphs, tables and diagrams described to hone students' communication skills. Another reason that shows students' lack of mathematical communication skills is the monotonous learning process where students only hear what the teacher has said. In addition, aspects of students' basic abilities also influence their mathematical communication skills.

NCTM (Hendriana, 2018: 60), states that mathematical communication is a basic mathematical competence that is essential to mathematics in mathematics education. Without good communication, mathematics development will be hampered. A symbol is a symbol or media that contains a specific purpose and purpose. Symbols of scientific communication can be tables, charts, graphs, pictures of mathematical equations and so on. 
If a student is said to be able to communicate mathematics, because it can express mathematical ideas in oral or written ways, describe, demonstrate, explore, investigate mathematics visually to share thoughts and findings, brainstorm, assess and sharpen ideas to convince others.

Communication skills are one way to increase student knowledge individually or in groups. With the aim that students can be motivated to learn mathematics and have a positive attitude towards mathematics and can improve communication skills, efforts are needed to create and be able to develop students' mathematical communication skills with fun learning. Therefore, the researcher applies an approach that is believed to be able to have a positive impact on the learning process so that it can be estimated that an increase in mathematical communication skills can be achieved, namely by applying the Realistic Mathematics Education (RME) approach this can hone and improve mathematical communication skills using everyday experiences. into real situations and provide opportunities for students to investigate and understand mathematical models in the form of communication skills questions on statistical material.

In previous research, Febriyanti et al, (2019), Tebe et al, (2019), Zulfakri, (2019) and Qadri et al, (2019) explained that students' ability to learn is largely determined by the learning model used by the teachers. Like Rahmah et al, (2020) said the development of teacher competence is in order to develop students' reasoning abilities through problem based learning. Not only that, the importance of building students' High Order Thinking (HoT) abilities can occur through good mathematical literacy (Oktiningrum \& Wardhani, 2020). This is also in line with the research of Nurjannah et al. (2020) to improve students' creative abilities, it is necessary to use technology, such as GeoGebra software. Therefore, teachers need to think of strategies and appropriate models to help students develop their abilities (Nartani et al, 2015; Qohar, Sumarmo, 2013; Rahmi et al, 2017).

Communication skills are considered as one of the most needed abilities today as an ability that helps students develop other abilities in mathematics (Nartani et al, 2015; Saragih, 2016; Powell \& Hebert, 2016), not only that, students' mathematical communication skills are initial ability to explore creativity (Nurjannah et al, 2020; Triana \& Zubainur, 2019; Johar et al, 2018; Paruntu et al, 2018). As stated in Herawaty et al's research, (2019) the ability to communicate mathematics in learning ethnomathematics greatly helped them understand mathematical concepts. Mathematical abilities are also marked by fluency in communication to express mathematical ideas through writing and non-writing (Trisnawati et al, 2018; Veloo et al, 2016; Hasibuan et al, 2019; Lomibao et al, 2016; Habsah, 2017).

According to Habsah (2017) through the development of teaching materials based on realistic mathematics learning, it is able to foster students' reasoning and communication skills. In line with what Fauzi \& Masrukan found, (2018) that learning mathematics with a realistic open-ended mathematics education approach can improve mathematics communication skills. Likewise, Trisnawati et al, (2018) that realistic mathematics education provides effectiveness in improving students' mathematical communication skills. For this reason, this paper focuses more on advanced research, namely the application of realistic mathematics education in statistics courses on mathematics communication skills.

Researchers used indicators of students' mathematical communication skills according to Sumarmo (Hendriana, 2018: 62), detailing mathematical communication indicators into several mathematical activities, including:

1. State the situation in the form of a picture and compile a mathematical model and solve it.

2. Linking images to mathematical ideas

3. Write down math ideas in your own words.

4. Describe the completion procedure.

Based on the above indicators, it can be concluded that students' mathematical communication skills are the ability to express mathematical ideas through oral and written. Students' oral mathematical communication skills can be measured when these students express their mathematical knowledge. Then students 'mathematical communication skills in writing can be measured through students' writing about mathematics. According to Jarmita (2013: 215), Realistic Mathematics Education (RME) is a theory in mathematics education based on the idea put forward by Freudenthal that mathematics is a human activity and mathematics must be connected significantly to the context of students' daily life. RME is a teaching approach that starts from real things for students, emphasizes the skills of 'the process of doing mathematics', discussing and collaborating, arguing with classmates so that they can find themselves (student inventing as the opposite of teacher telling). mathematics to solve problems both individually and in groups. In this approach, the teacher's role as a facilitator, moderator or evaluator while students think, communicate ideas and opinions to train democratic nuances by respecting the opinions of others. According to Sukasmi (2004: 13) this step refers to the characteristics of Realistic Mathematics Education, namely using contextual problems as the starting point in this activity. Realistic mathematics learning process in this study is: 
Step 1. Describe the contextual problem.

Step 2. Resolve contextual problems.

Step 3. Compare and discuss answers.

Step 4. Summing up. The teacher directs students to draw conclusions on a concept or procedure. The characteristics of Realistic mathematics education that appear in this step are the fourth characteristics, namely the interaction between students and teachers as guides (Sukasmi, 2004: 15).

By applying the RME approach to learning, students are able to understand statistical material in real terms such as measuring height using a measuring instrument in the form of a tape measure or other examples such as weighing with a scale, therefore students are able to apply mathematics in real terms in the daily life of students. so that it can be estimated to be able to improve students' mathematical communication skills. Based on the background of the problems described above, the researchers are interested in conducting research with the title of implementing the Realistic Mathematics Education (RME) approach to improve students' mathematical communication skills in the statistical material of MTs.S Syamsuddhuha.

\section{Methods}

This study uses a quantitative approach with the type of research that is quasi-experimental (quasiexperimental). The design used by researchers in this study is the Non-Equivalent Pretest-Posttest Control Group Design. In accordance with the research objectives, namely to determine the application of the Realistic Mathematics Education (RME) learning approach to improving the mathematical communication skills of grade VII students in statistics material. This type of research uses pretest and posttest research designs to determine students' initial and final abilities. The design is as follows:

Table 1. Research Design

\begin{tabular}{cccc}
\hline Treatment group & Pre-test & Treatment & Post-test \\
\hline Experiment & $\mathrm{O}_{1}$ & $\mathrm{X}$ & $\mathrm{O}_{2}$ \\
Control & $\mathrm{O}_{3}$ & & $\mathrm{O}_{4}$ \\
\hline
\end{tabular}

Sources: Modified from Sugiyono (2017: 116).

Information:

$0_{1} \quad=$ Pre-test for the experimental class

$\mathrm{O}_{3}=$ Pre-test for control class

$\mathrm{X} \quad=$ Experimental learning treatment

$\mathrm{O}_{2} \quad=$ Post-test for the experimental class

$\mathrm{O}_{4} \quad=$ Post-test for control class

In this study, the experimental class was taught using the Realistic Mathematics Education (RME) approach and the control class used the conventional learning approach. At the beginning of learning, both classes were given a pretest to determine the initial abilities of the two classes. And the material taught for the two classes is the same, namely statistics. At the end of the learning process, the two classes were given a posttest to determine the level of achievement of student learning achievement that had been delivered.

This research was conducted in class VII MTs.S Syamsudduha. The reasons for choosing the location of this study were due to the following considerations:

1. Based on the observations of MTs.S Syamsudduha, the researcher saw that there were still many who lacked communication skills, and it was still difficult to understand the material taught by the teacher so that student learning achievement looked low.

2. The opening of the possibility to conduct research using the Realistic Mathematics Education (RME) learning model, because a study has been conducted with other models and on other materials it turns out that the results can improve student achievement.

3. The school is close to the researcher, because it can save transformation costs in research.

The population in this study were all students of class VII MTs.S Syamsudduha which consisted of 4 classes with an average of 30 students per class. Samples taken in this study using purposive sampling technique. So the sample in this study is class VII-1 as the experimental class and VII-2 as the control class which is estimated to have the same abilities. Sampling with this technique with the aim is good enough because it is in accordance with the researcher's own considerations, so that it can represent the population.

In this study, the test type instrument was a test of students' mathematical communication skills which consisted of 4 questions in the form of descriptions concerning the material amount and the difference between two angles with an allocation of 90 minutes. The grid and alternative items for the answer to the mathematical communication ability test are as follows: 


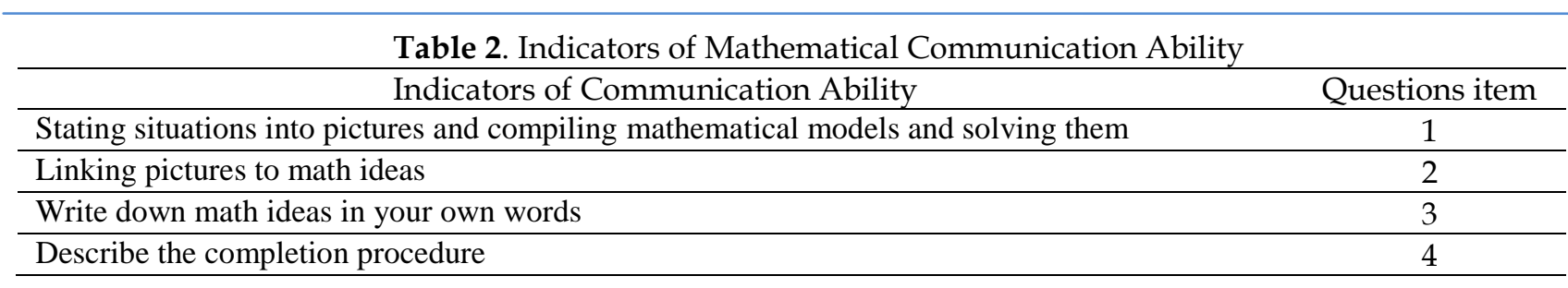

To make it easier to score students' mathematical communication skills, a scoring alternative is presented and used in this study.

Table 3. Guidelines for Assessing Mathematical Communication Skills

\begin{tabular}{|c|c|c|}
\hline Rated aspect & Students' Answers & Scores \\
\hline \multirow{5}{*}{$\begin{array}{l}\text { Expressing situations into } \\
\text { pictures, and compiling } \\
\text { mathematical models and } \\
\text { solving them. }\end{array}$} & 1. No answer at all & 0 \\
\hline & $\begin{array}{l}\text { 2. Not expressing situations in the form of pictures and compiling } \\
\text { mathematical models and not solving them. }\end{array}$ & 1 \\
\hline & $\begin{array}{l}\text { 3. Stating situations into pictures and compiling mathematical models } \\
\text { and solving them but not true }\end{array}$ & 2 \\
\hline & $\begin{array}{l}\text { 4. Stating situations into pictures and compiling mathematical models } \\
\text { and solving them but incomplete }\end{array}$ & 3 \\
\hline & $\begin{array}{l}\text { 5. Stating situations into pictures and compiling mathematical models } \\
\text { and solving them correctly and completely }\end{array}$ & 4 \\
\hline \multirow{5}{*}{$\begin{array}{l}\text { Linking pictures to math } \\
\text { ideas }\end{array}$} & 1. No answer at all & 0 \\
\hline & $\begin{array}{l}\text { 2. Do not write mathematical ideas at all into a mathematical model } \\
\text { 3. Writing math ideas into mathematical models is not correct }\end{array}$ & 1 \\
\hline & 4. Writing mathematical ideas into a mathematical model correctly but & 2 \\
\hline & not completely & 3 \\
\hline & $\begin{array}{l}\text { 5. Write mathematical ideas into a mathematical model correctly and } \\
\text { completely }\end{array}$ & 4 \\
\hline \multirow{5}{*}{$\begin{array}{l}\text { Write down math ideas in } \\
\text { your own words }\end{array}$} & 1. No answer at all & 0 \\
\hline & 2. Do not link the image at all to the math idea & 1 \\
\hline & 3. Linking images into math ideas but not correct & 2 \\
\hline & 4. Correctly linking the image into a mathematical idea but not complete & 3 \\
\hline & 5. Correct and complete connection of pictures into math ideas & 4 \\
\hline \multirow{5}{*}{$\begin{array}{l}\text { Describe the completion } \\
\text { procedure }\end{array}$} & 1. No answer at all & 0 \\
\hline & 2. Does not explain the settlement procedure at all & 1 \\
\hline & 3. Explain the completion procedure incorrectly & 2 \\
\hline & 4. Explains the completion procedure correctly but is incomplete & 3 \\
\hline & 5. Explain the completion procedure correctly and completely & 4 \\
\hline
\end{tabular}

Sources: Modified from Ansari, (2009: 78).

Researchers used the test instrument test questions first by using the validity, reliability, distinguishing power, and difficulty level tests. This research was conducted using three data collection techniques, including using the test method, observation sheet, and the decomentation methods.

\section{Results and Discussions}

\subsection{Results}

This research was conducted to determine whether the application of the Realistic Mathematics Education (RME) approach to improve students' mathematical communication skills in statistical material carried out at MTs.S Syamsuddhuha on March 23 to April 2 2019. In this study, using two classes, namely the experimental class as The class that received treatment through the RME approach was in class VII-1 consisting of 34 students and the untreated control class in class VII-2 which consisted of 36 students. The data analyzed were obtained from the pretest scores given at the beginning of the lesson, the post-test scores given at the end of the lesson. Results of the Calculation of Test Instruments for Validity, Reliability, Level of Difficulty and Distinguishing Powers.

Validity

Based on the results of the calculation of the validity test of the test items conducted at MTs.S Syamsudduha, it shows that:

a. Validity, Reliability, Distinguishing Power, Difficulty Level of Mathematical Communication Ability Test Questions 
Table 4. Validity, Reliability, Distinguishing Power, Difficulty Level of Mathematical Communication Ability Tests

\begin{tabular}{|c|c|c|c|c|c|c|c|c|c|}
\hline \multirow{2}{*}{$\begin{array}{l}\text { Question } \\
\text { Item }\end{array}$} & \multicolumn{2}{|c|}{ Validity } & \multicolumn{2}{|c|}{ Reliability } & \multicolumn{2}{|c|}{ Distinguishing Powers } & \multicolumn{2}{|c|}{ Level of Difficulty } & \multirow[b]{2}{*}{ Description } \\
\hline & $\begin{array}{c}\text { Correlation } \\
\text { coefficient }\end{array}$ & Interpretation & $\begin{array}{c}\text { Correlation } \\
\text { coefficient }\end{array}$ & Interpretation & Indeks & Interpretation & Indeks & Interpretation & \\
\hline 1 & 0,72 & High Validity & \multirow{6}{*}{0,90} & \multirow{6}{*}{$\begin{array}{l}\text { Very High } \\
\text { Reliability }\end{array}$} & 0,39 & Moderate & 0,37 & Good & Used \\
\hline 2 & 0,84 & $\begin{array}{l}\text { Very High } \\
\text { Validity }\end{array}$ & & & 0,39 & Difficult & 0,22 & Good & Used \\
\hline 3 & 0,72 & High Validity & & & 0,48 & Easy & 0,71 & Very Good & Used \\
\hline 4 & 0,72 & High Validity & & & 0,31 & Moderate & 0,31 & Good & Used \\
\hline 5 & 0,56 & $\begin{array}{l}\text { Validity } \\
\text { Enough }\end{array}$ & & & 0,13 & Difficult & 0,16 & Not good & Deleted \\
\hline 6 & 0,57 & $\begin{array}{l}\text { Validity } \\
\text { Enough }\end{array}$ & & & 0,08 & Difficult & 0,04 & Not good & Deleted \\
\hline
\end{tabular}

Based on table 1.6 above, the results of the validity test of students' mathematical communication skills from 6 items number 1,3, and 4 have high validity and number two has very high validity then numbers 5 and 6 have sufficient validity. Where based on the results of the reliability calculation, the mathematical communication skills test questions have very high reliability. Therefore, the level of difficulty obtained from the 6 items on the mathematical communication ability test that deserves to be accepted becomes 4 test items because questions number 5 and 6 are classified as difficult. Then the questions number 1, 2, and 4 have a good level of difficulty and number 3 has a very good level of difficulty similar to those in questions 5 and 6 it has a poor level of difficulty so that test questions number 5 and 6 are discarded or not suitable for use . Therefore, the researcher chose questions number 1,2,3, and 4 which were appropriate to be used as pre-test and post-test questions for the students' mathematical communication ability test. Based on data analysis, the results of the study were obtained through tests of students' mathematical communication skills that the test had been given twice, namely before and after the students were treated in different classes of treatment. The following is a table describing the descriptive data of the pre-test, post-test and normalized gain $(\mathrm{N}$ gain) of students' mathematical communication abilities.

Table 5. Data on Students' Mathematical Communication Ability Scores

\begin{tabular}{|c|c|c|c|c|c|c|c|c|c|}
\hline \multirow{2}{*}{ Abilities/Skills } & \multirow{2}{*}{ Scores } & \multicolumn{4}{|c|}{ Experiment } & \multicolumn{4}{|c|}{ Control } \\
\hline & & $\mathrm{N}$ & $\overline{\bar{x}}$ & $\mathrm{~S}$ & $\%$ & $\mathrm{~N}$ & $\bar{x}$ & $\mathrm{~S}$ & $\%$ \\
\hline \multirow{4}{*}{ Communication Skills } & Pretes & 34 & 2,61 & 3,284 & 0,15 & 36 & 1,66 & 0,800 & 0,10 \\
\hline & Posttest & 34 & 8,85 & 10,553 & 0,55 & 36 & 4,91 & 5,107 & 0,30 \\
\hline & $\mathrm{N}$-gain & 34 & 0,45 & & & 36 & 0,22 & & \\
\hline & \multicolumn{9}{|c|}{ Maximum Scores $=16$} \\
\hline
\end{tabular}

Based on table 5, it is found that the pre-test average of mathematical communication skills in the experimental class is 2.61 and the control class is 1.66 with an ideal maximum score of 16 . It shows that the pretest average of the two classes is almost equal because their mathematical communication skills are relatively the same.

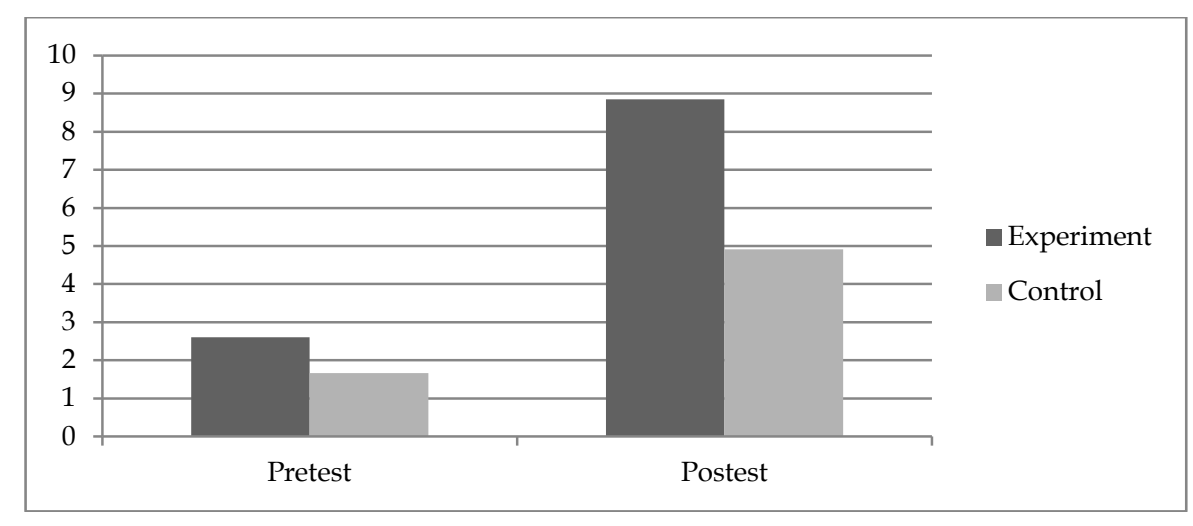

Figure 2. Mean of Mathematical Communication Ability Pretest Scores

From Figure 2 above shows that the average pretest score of students' mathematical communication skills for the experimental class and the control class is different, because that the initial abilities of the two classes before being treated are relatively the same. This is because the average post-test score in the experimental class is higher than the control class so that there is an increase in the score of students' mathematical communication skills after learning with the Realistic Mathematics Education approach. The n-gain average value can be seen in Figure 3. 


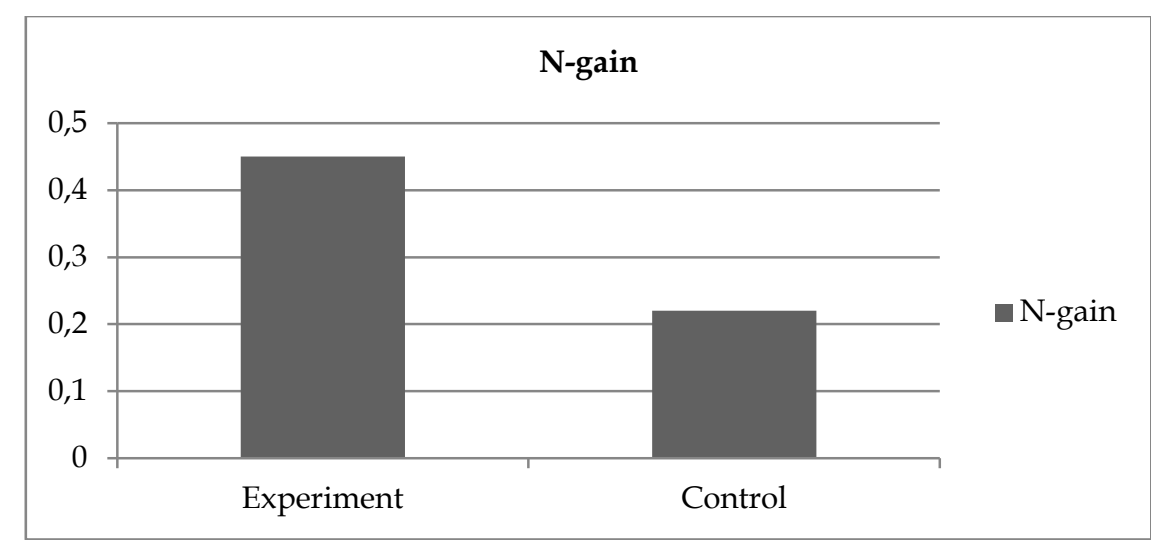

Figure 3. Average N-gain of Mathematical Communication Ability

Figure 3 above shows that the average $\mathrm{N}$-gain of the experimental class has an average of 0.45 , while in the control class the average value is 0.22 . From the results of this study states that applying the Realistic Mathematics Education approach can improve the mathematical communication skills of students taught in class VII-1 on statistics material. Based on the calculation of the n-gain value on students' mathematical communication skills, the n-gain value data obtained is 0.45 so that the interpretation of the gain index criteria is moderate. The normality test in this study used the Shapiro-Wilk technique. Where the data that has been obtained is greater than a significant value of 0.05 , the data is normally distributed and acceptable.

Table 6. Normality Test Results of Students' Mathematical Communication Data on Students

\begin{tabular}{cccc}
\hline Variable & Control Class & Experiment Class & Description \\
\hline Signifikan & 0,171 & 0,497 & Normal \\
\hline
\end{tabular}

The results of table 6 show that the results of the data normality test of students' mathematical communication skills in the control class obtained a value of 0.171 and the experimental class obtained a value of 0.497 , both classes obtained a significant value. Then the results of the two classes $>0.05$ then Ho is accepted. So that the test scores of mathematical communication skills are normally distributed. Homogeneity test is used to determine whether a data or sample taken comes from a homogeneous variant or not. Data that is homogeneous if $\mathrm{p}>0.05$, and if the data is not homogeneous if $\mathrm{p}<0.05$. The homogeneous test here is carried out using the Levene test. The results of the data homogeneity test for the experimental class and control class are presented in table 7.

Table 7. Homogeneity Test Results of Mathematical Communication Ability Data

\begin{tabular}{cccc}
\hline Levene Statistic & df 1 & df 2 & Sig \\
\hline 5,459 & 1 & 68 & 0,022 \\
\hline
\end{tabular}

The results of the homogeneous test table 1.9 data on students 'mathematical communication skills in the experimental class get a value of 0.022 , so the $\mathrm{p}$ value (significant) $<0.05$ so it can be concluded that the variants in the data on students' mathematical communication skills that have been obtained do not have the same variant so that the data is not homogeneous. Based on the results of the normality test and the homogeneity of the variance test, the results of the data on students' mathematical communication skills for the experimental group and the control group are normally distributed and do not have the same variance, the data is not homogeneous. Based on these data, the hypothesis is tested by doing the t-test.

Table 8. Summary of the t-test

\begin{tabular}{cccc}
\hline Statistic & $\mathrm{T}$ & $\mathrm{Df}$ & Sig.(1-tailed) \\
\hline Equal Variances not assumed & 4.173 & 60.83 & 0.000 \\
\hline
\end{tabular}

From the results of hypothesis testing table 8 through t-test analysis using SPSS 18 from the data on students' mathematical communication skills obtained $0.00<0.05$, then Ho is rejected Ha accepted. So that the mathematical communication skills of students who are taught by applying the Realistic Mathematics Education approach are higher than those taught through conventional learning models. Teacher activity in implementing classroom learning has a very influential on student learning outcomes, this is identified in teachers who have carried out the stages of implementing the RME approach in the following classes are the results of peer observations to assess researchers at the time of research. In this case, the teacher's activities in implementing RME learning are classified as good with the achievement of an average value of 3.05 where each meeting has increased which is presented in the following figure 4. 


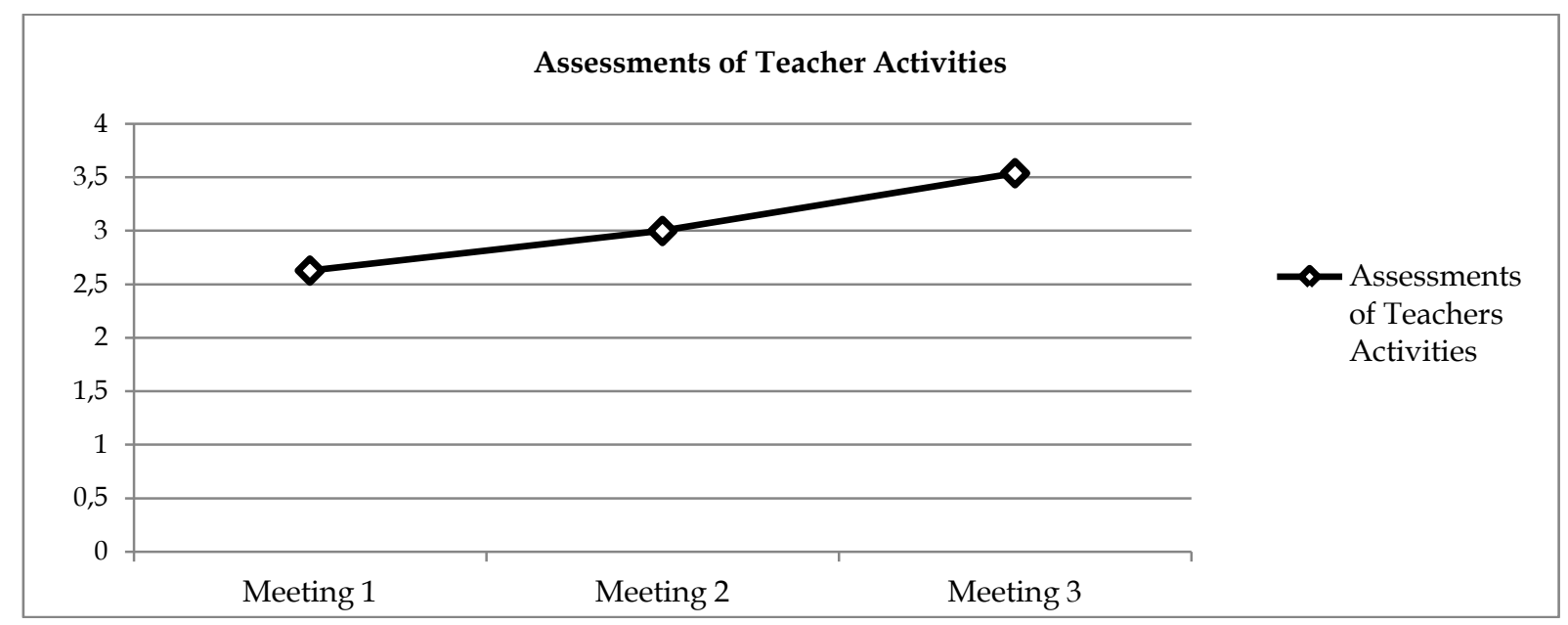

Figure 4. Diagram of Teachers Activity Assessments

Based on Figure 4 above, it is clear that the assessment of teacher activity from the first meeting to the third meeting has increased. It can be concluded that teachers are trying to improve the learning process to be even better with the aim of achieving learning by applying a better Realistic Mathematics Education approach. So, the data on the scale of teacher activity while researching obtained a score percentage of $76 \%$ so it was categorized as good.

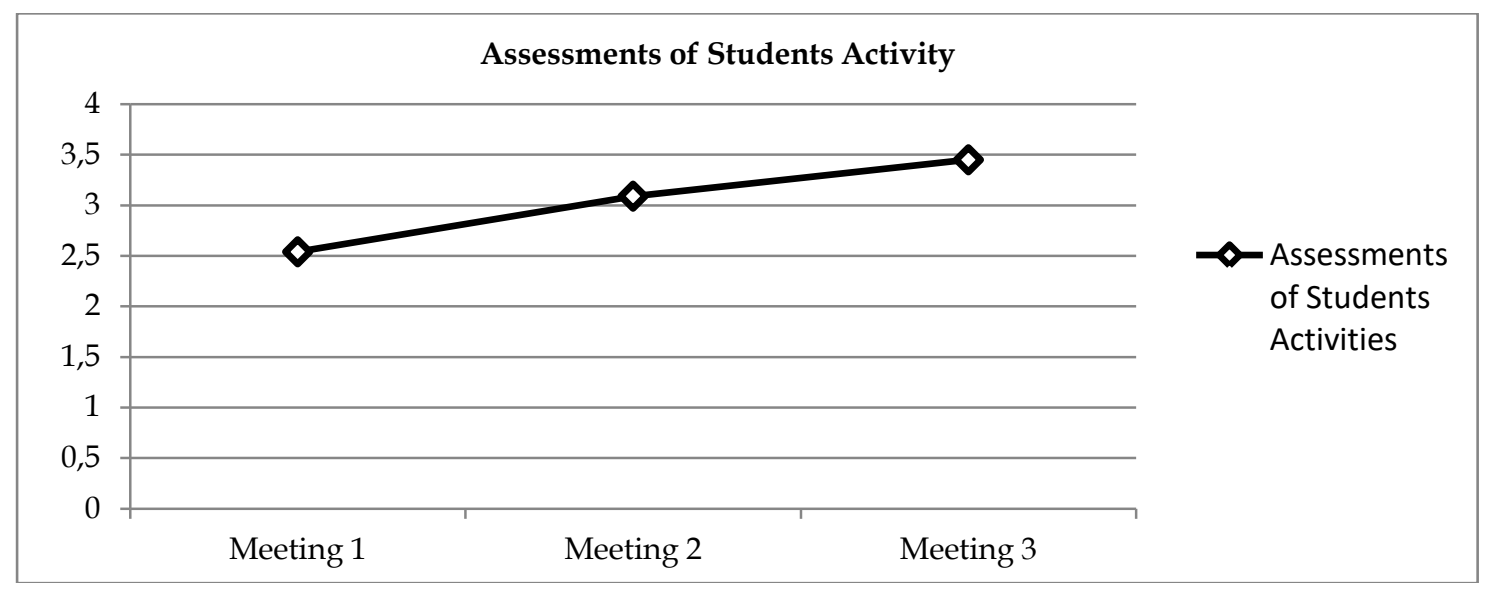

Figure 5. Diagram of Students Activity Assessments

From Figure 5 above, it can be seen that student activity in each meeting has increased. This is because students are getting used to the learning approach applied by the teacher. So, the student activity scale score data during the treatment obtained a percentage score of $75 \%$ so it was categorized as good.

\subsection{Discussion}

Based on the results of the study, it shows that the analysis obtained in testing this hypothesis turns out that students' mathematical communication skills taught through the Realistic Mathematic Education approach are better than students taught conventionally at MTs.S Syamsudduha. This is in accordance with the results of research data which show that the mean value for the experimental class $\vec{x}=8.85$ and for the control class mean $\vec{x}=4.91$ from the two mean values, there is a clear difference. Learning using the Realistic Mathematic Education approach can improve students' mathematical communication skills due to the way students learn by connecting material to the real world such as statistical material regarding height measurement presented in diagrams so that students better understand the material that has been studied. Unlike the case with conventional learning, learning activities are only based directly on the teacher who provides the presentation of the learning content. The teacher is the only source of information so that students only actively listen. Students are not directly involved in learning except when the teacher provides the opportunity to ask questions about the learning content that students have not understood by the teaching 
provided by the teacher. By applying the Realistic Mathematics Education approach students are more enthusiastic about the ongoing learning as showed in figure 6.

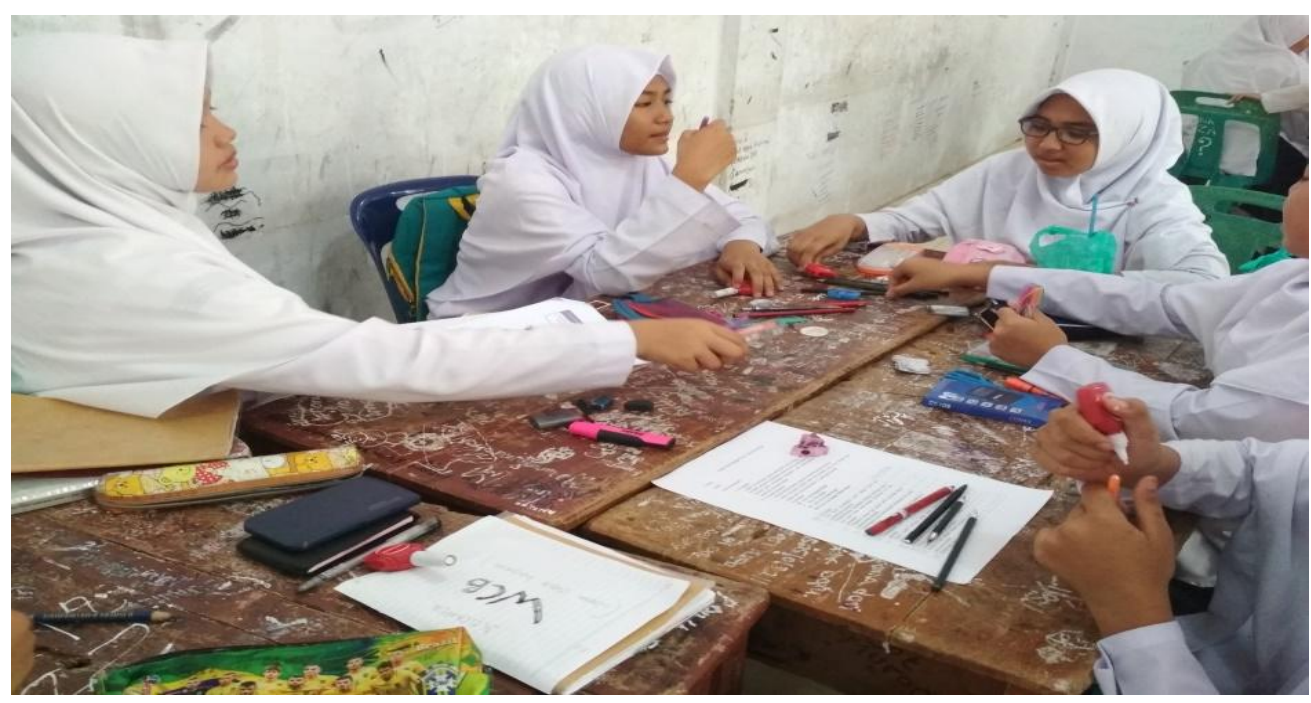

Figure 6. Students Activities in Solve Problems with Student Worksheets

Students interact more with their group friends in doing with Student Worksheets LAS so that in answering existing problems students must be able to communicate correctly so that what they say fulfills their aims and objectives, in working on these questions students appear to be calculating the writing tools they get from their group friends to collect the stationery data they use in class in making bar charts to solve existing problems. So, from the data on the scale of teacher and student activity during the learning process, the percentage score of $76 \%$ for the teacher and $75 \%$ of the student's score is categorized as good. The learning carried out by the researcher is in accordance with the expectations of the researcher, which is to improve communication skills by applying the RME approach. The learning process using the RME approach can make students active in teaching and learning activities in class. Student and teacher activities are very important to determine whether or not there is an improvement in a learning approach. Based on the results of observations of student and teacher activities during the learning process using the RME approach, it can be categorized as good.

Based on Trisnawati's research, (2013: 615), and Purwandari, (2014), which states that students are very happy in the learning process using real objects. So that students more easily understand the material provided and are active in class learning. So Trisnawati concluded that mathematics learning activities with the RME approach can improve mathematical communication of grade VII students. The constraints faced by the researcher were when implementing the RME Approach there were some students who were less interested in learning such as there were still students who fell asleep in the classroom during learning and there were still many students who lacked confidence to present their group work and there were still students who left entering class without asking permission first, then there are still many students who are not enthusiastic about learning mathematics so that researchers still have difficulty in livening up the learning atmosphere. However, researchers can overcome these problems by motivating, providing direction and encouraging students to be more active when the learning takes places.

\section{Conclusion}

Based on the results of the data analysis obtained by the researcher, it can be concluded that the students' mathematical communication skills applied through the Realistic Mathematic Education approach are better than those applied with conventional learning because by applying mathematics in class students are easier to understand and able to convey material that has been understood by means of a group percentage.

\section{Acknowledgement}

The authors would like to thanks to the supervisors who have been instrumental in their assistance and the successful completion of this study.

\section{Author's Contributions}

All authors discussed the results and contributed to from the start to final manuscript. 


\section{Conflict of Interest}

The authors declare that they have no competing interests.

\section{References}

Adinawan, M.C. 2016. Matematika SMP/MTs Jilid 1B Kelas VII Semester 2 Berdasarkan Kurikulum 2013 Revisi. Ciracas, Jakarta. Erlangga.

Ansari, I,B. (2009). Komunikasi matematik Konsep Dan Aplikasi. Banda Aceh: Yayasan PeNA.

Etuk, E. N., Afangideh, M. E., \& Uya, A. O. (2013). Students' Perception of Teachers' Characteristics and Their Attitude towards Mathematics in Oron Education Zone, Nigeria. International Education Studies, 6(2), 197-204.

Fauzi, A., \& Masrukan, M. (2018). Math learning with realistic mathematics education approach (rme) based on open source-ended to improve mathematic communication. Journal of Primary Education, 7(1), 10-17.

Febriyanti, F., Bagaskorowati, R., \& Makmuri, M. (2019). The Effect of The Realistic Mathematics Education (RME) Approach and The Initial Ability of Students on The Ability of Student Mathematical Connection. International Journal for Educational and Vocational Studies, 1(3), 153-156

Habsah, F. (2017). Developing teaching material based on realistic mathematics andoriented to the mathematical reasoning and mathematical communication. Jurnal Riset Pendidikan Matematika, 4(1), 4355.

Hasibuan, A. M., Saragih, S., \& Amry, Z. (2019). Development of Learning Materials Based on Realistic Mathematics Education to Improve Problem Solving Ability and Student Learning Independence. International electronic journal of mathematics education, 14(1), 243-252.

Hasratuddin. (2014). Pembelajaran Matematika Sekarang dan yang akan Datang Berbasis Karakter. Jurnal Didaktik Matematika. 1(1): 30.

https://www.sciepub.com/reference/217130/. Akses tanggal 26 Februari 2019.

Herawaty, D., Widada, W., Adhitya, A., Sari, R. D., Novianita, L., \& Anggoro, A. F. D. (2020, February). Students' ability to simplify the concept of function through realistic mathematics learning with the ethnomathematics approach. In Journal of Physics: Conference Series (Vol. 1470, No. 1, p. 012031). IOP Publishing.

Hendriana, H., Rohaeti, E.E., \& Sumarno, U. (2018). Hard Skills dan Soft Skills. Bandung: PT Refika Aditama.

Herawaty, D., Gusri, S. A., Saputra, R., Liana, E., \& Aliza, F. (2019, October). The mathematics communication of students in learning based on ethnomathematics Rejang Lebong. In Journal of Physics: Conference Series (Vol. 1318, No. 1, p. 012074). IOP Publishing.

Jarmita, N. \& Hazami. (2013). Ketuntasan Hasil Belajar Siswa Melalui Pendekatan Realistic Mathematics Education (RME) pada Materi Perkalian. Jurnal Ilmiah DIDAKTIKA. VOL. XIII, NO. 2, 212-222.

https://media.neliti.com/media/publications/136804-ID-ketuntasan-hasil-belajar-siswa-melaluip.pdf/. Akses tanggal 24 Februari 2019.

Johar, R., Junita, E., \& Saminan, S. (2018). Students' Mathematical Communication Ability and Self-Efficacy using Team Quiz Learning Model. International Journal on Emerging Mathematics Education, 2(2), 203214.

Lomibao, L. S., Luna, C. A., \& Namoco, R. A. (2016). The influence of mathematical communication on students' mathematics performance and anxiety. American Journal of Educational Research, 4(5), 378-382.

Marhami (2016). Pengaruh Strategi Pembelajaran Konflik Kognitif terhadap Kemampuan Pemahaman Relasional dan Komunikasi Matematis serta Self-Regulation Siswa SMP. Tesis. Universitas Pendidikan Indonesia.

Nartani, C. I., Hidayat, R. A., \& Sumiyati, Y. (2015). Communication in mathematics contextual. International Journal of Innovation and Research in Educational Sciences, 2(4), 284-287.

Nurjannah, N., Subianto, M., \& Abidin, Z. (2020). Effectiveness of Tangent Equation Curve Learning through GeoGebra Software Assisted Module to Improve Student's Creative Mathematical Thinking Skills. International Journal for Educational and Vocational Studies, 1(8).

Oktiningrum, W., \& Wardhani, D. A. P. (2020). Developing Hot Mathematics Task with Indonesian Heritage as Context to Assess Mathematical Literacy of Students in Primary School. International Journal for Educational and Vocational Studies, 2(1).

Paruntu, P. E., Sukestiyarno, Y. L., \& Prasetyo, A. P. B. (2018). Analysis of Mathematical Communication Ability and Curiosity Through Project Based Learning Models With Scaffolding. Unnes Journal of Mathematics Education Research, 7(1), 26-34.

Powell, S. R., \& Hebert, M. A. (2016). Influence of writing ability and computation skill on mathematics writing. The elementary school journal, 117(2), 310-335. 
Purwandari, Y. (2014). Pengembangan Perangkat Pembelajaran Statistika Menggunakan Pendekatan Kontekstual Berorientasi pada Kemampuan Komunikasi Matematis Siswa SMP Kelas VII. Skripsi. Yogyakarta: Universitas Negeri Yogyakarta.

http://eprints.uny.ac.id/id/eprint/12553/. Akses tanggal 24 Februari 2019.

Qadri, L., Ikhsan, M., \& Yusrizal, Y. (2019). Mathematical creative thinking ability for students through REACT strategies. International Journal for Educational and Vocational Studies, 1(1), 58-61.

Qohar, A., \& Sumarmo, U. (2013). Improving Mathematical Communication Ability and Self Regulation Learning of Junior High Students by Using Reciprocal Teaching. Indonesian Mathematical Society Journal on Mathematics Education, 4(1), 59-74.

Rahmah, S., Johar, R., \& Saminan, S. (2020). The Development of Teacher Efforts to Improve The Mathematical Reasoning Abilities Through The Problem Based Learning. International Journal for Educational and Vocational Studies, 1(8).

Rahmi, S., Nadia, R., Hasibah, B., \& Hidayat, W. (2017). The relation between self-efficacy toward math with the math communication competence. Infinity Journal, 6(2), 177-182.

Saragih, S. (2016). The profile of communication mathematics and students' motivation by joyful learningbased learning context Malay culture. Journal of Education, Society and Behavioural Science, 1-16.

Sugiyono, (2017). Metode Penelitian Pendidikan Pendekatan Kuantitatif, Kualitatif, dan RED. Bandung. Alfabeta.

Sukasmi. (2004). Upaya Meningkatkan Aktivitas dan Hasil Belajar Matematika Melalui Pendekatan Realistic Mathematics Eeducation (RME) Siswa Kelas V SD Negeri 10 Curup Timur. Skripsi. Bengkulu: Universitas Bengkulu.

http://repository.unib.ac.id/id/eprint/8879/. Akses tanggal 20 Februari 2019.

Suyitno, A., \& Suyitno, H. (2015). Learning therapy for students in mathematics communication correctly based-on application of newman procedure (a case of indonesian student). International Journal of Education and Research, 3(1), 529-538.

Tambunan, H. (2018). Impact of Heuristic Strategy on Students' Mathematics Ability in High Order Thinking. International Electronic Journal of Mathematics Education, 13(3), 321-328.

Tebe, S. R., Anwar, A., \& Bahrun, B. (2019). Effectiveness of Mathematical Learning Devices Based on Verbal Linguistic Intelligence and Mathematical Logical Intelligence. International Journal for Educational and Vocational Studies, 1(4), 304-307.

Tim dosen sekolah tinggi agama islam gajah putih takengon. (2008). Bunga rampai pemikiran tentang pendidikan. Takengon. STAI Gajah Putih Press.

Tinungki, Georgina Maria. "The Role of Cooperative Learning Type Team Assisted Individualization to Improve the Students' Mathematics Communication Ability in the Subject of Probability Theory." Journal of Education and Practice 6.32 (2015): 27-31.

Triana, M., \& Zubainur, C. M. (2019). Students' Mathematical Communication Ability through the BrainBased Learning Approach Using Autograph. Journal of Research and Advances in Mathematics Education, $4(1), 1-10$.

Trisnawati. (2013). Upaya meningkatkan kemampuan komunikasi matematis siswa kelas vii dalam pembelajaran matematika dengan pendekatan realistic mathematics education (RME) di SMP Negeri 1 Muntilan. Prosiding. Yogyakarta: Universitas Negeri Yatama.

Trisnawati, T., Pratiwi, R., \& Waziana, W. (2018). The effect of realistic mathematics education on student's mathematical communication ability. Malikussaleh Journal of Mathematics Learning (MJML), 1(1), 31-35.

Undang-Undang Republik Indonesia No. 14 Tahun 2005 Tentang Guru dan Dosen. http://luk.staff.ugm.ac.id/atur/UU14-2005GuruDosen.pdf/. Akses tanggal 25 Februari 2019.

Vale, I., \& Barbosa, A. (2017). The importance of seeing in mathematics communication. Journal of the European Teacher Education Network, 12, 49-63.

Veloo, A., Md-Ali, R., \& Chairany, S. (2016). Using Cooperative Teams-Game-Tournament in 11 Religious School to Improve Mathematics Understanding and Communication. Malaysian Journal of Learning and Instruction, 13(2), 97-123.

Zulfakri, Z., Ikhsan, M., \& Yusrizal, Y. (2019). Improving the Ability of Representation and Problem Solving Through Concrete Representational Abstract (CRA) Approach in Mathematical Learning. International Journal for Educational and Vocational Studies, 1(3), 244-248. 